\title{
Differentiation and Distinction: On the Problem of Individuation from Scotus to Deleuze
}

\section{Gil Morejón DePaul University}

\begin{abstract}
In this paper I present an interpretation of Deleuze's concept of the virtual. I argue that this concept is best understood in relation to the problematic of individuation or differentiation, which Deleuze inherits from Duns Scotus. After analysing Scotus' critique of Aristotelian or hylomorphic approaches to the problem of individuation, I turn to Deleuze's account of differentiation and his interpretation of the calculus in chapter 4 of Difference and Repetition. The paper seeks thereby to explicate Deleuze's dialectics or theory of Ideas, his approach to the principle of sufficient reason, and the concept of the virtual itself.
\end{abstract}

Keywords: Deleuze, Scotus, differentiation, individuation, dialectics, calculus

\section{Introduction}

The philosophical thread uniting the work of Duns Scotus and Gilles Deleuze is, more than a shared commitment to the ontological doctrine of univocity, a rigorous pursuit of a metaphysics of individuation, exploring the consequences of a fundamental insight: that what exists prior to individuation or differentiation, which is figured variously as the 'common nature' and the 'virtual', is not at all undifferentiated. ${ }^{1}$ This is an important insight because it forces a re-evaluation of the

Deleuze and Guattari Studies 12.3 (2018): 353-373

DOI: $10.3366 /$ dlgs.2018.0316

(C) Edinburgh University Press www.euppublishing.com/dlgs 
idea of possibility, which was classically understood as the negation of actuality, as in Aristotelian metaphysics. Hegel's famous critique, that Schelling's philosophy of Indifferenz amounted to the 'night where all cows are black', exposes the poverty of such a conception, by means of which we ultimately are left incapable of accounting for the reality of actual individuals or distinguishing between empirical instances (Hegel 2004: 9). Deleuze's metaphysics, with its emphatic insistence on the category of the virtual, means to eliminate entirely the idea of possibility as a kind of transcendental illusion: in fact, for Deleuze, as a thoroughgoing Spinozist, nothing is possible (Peden 2014: 227-36; Zourabichvili 1998). ${ }^{2}$ The positive notion of common nature or virtuality, as something both completely determined and undifferentiated, far exceeds in its explanatory capacities a negative notion of possibility as purely indifferent. ${ }^{3}$ But in order to think this pre-individual nature, to pose philosophically the problem of genesis, as Scotus already demonstrates and as we will see, it is necessary to abandon hylomorphism, the metaphysical theory according to which entities are understood as a combination of matter and form.

Why do we say 'individuation or differentiation'? We mean this not in the sense of an alternative but in the sense of a Spinozist Deus sive Natura - that is, as a polemical formulation indicating an inclusive disjunction. ${ }^{4}$ To the extent that one thinks the individual under the aspect of identity, one might conclude that individuation and differentiation are opposed. However, the individual is precisely distinct insofar as it is not identical to other individuals, although the positive account of in what this nonidentity consists may remain obscure. For this reason, Scotus is already able to develop a concept of singularity whose fundamental character is its irreducibility or uniqueness with respect to what is common-and which is opposed to a concept of individuality whose fundamental character is its indifferent participation in relation to a universal. Moreover, this peculiar coincidence of irreducibility and commonness in actual singularity cannot be conceived in terms of negation, but only by reference to the positivity of a difference. In other words, the process by which differentiation unfolds is precisely that of the genesis of individuals.

In what follows, we will first assess Scotus' critique of the conceptual inadequacy of Aristotelian hylomorphism regarding the issue of individuation: neither form, matter, nor their relationship can provide a convincing account of what constitutes an individual. Scotus' exhaustive negative-critical analysis yields the positive result that some minimal immanent criteria are ascertained regarding the problem of individuation 
and the concept of common nature. Subsequently we will turn to Deleuze, and in particular to his interpretation of differential calculus, since it is here that he identifies substantial resources for thinking the process of differentiation, which he articulated in terms of the actualisation of a problematic Idea (his theory of dialectics). Thus we will ask: why does Deleuze turn to the calculus, and what is at stake in his interpretation of it? For although Deleuze's reference to the calculus does not commit him to a mathematical ontology à la Badiou, he nevertheless clearly insists that neither is it to be understood as a mere metaphor. ${ }^{5}$ Instead, the metaphysics of differential calculus provides a model for grasping how, according to Deleuze and following the insights of Scotus, the pre-individual real is completely determined in a way that is obscure (rather than clear) and distinct.

\section{Scotus and the Immanent Critique of Individuation}

The medieval philosopher and theologian Duns Scotus asks: how can we account for individuality? To reformulate this question in such a way that elucidates the intimate connection between individuation and differentiation, we might say: how is a specific difference-the difference that distinguishes the essence of one species from that of another within the same genus or generic difference - itself differentiated into individuals of that species? To answer this question, the Aristotelian framework that formed the conceptual and metaphysical basis for much of the scholastic tradition would prove inadequate. Scotus' exhaustive method shows that none of the received categories could possibly account for this differentiation of specific differences, and thus that this problematic of individuation requires the development and deployment of new categories entirely: no longer the universal, but the common; no longer the individual, but the singular. Let us follow his path and join in the exhaustion, seeking the point at which there are no more possibilities; from this vantage point, significant characteristics of the common nature will become apparent.

In Ordinatio II, Distinction 3, Part I, sometimes referred to as the Treatise on the Common Nature and Individuation, Scotus takes up this problem, rejecting in turn the following suggestions for what could count as a principium individuationis: 1 . that things are individual by virtue of their nature (question 1); 2. that things are individual by virtue of a double negation (question 2); 3. that things are individual by virtue of their act of existing (question 3); 4. that things are individual by virtue of their accidents, in particular their quantity 
(question 4); and 5. that things are individual by virtue of their matter (question 5). The first two rejections establish the coordinates within which the rest of his investigation proceeds: they make it clear that our principle must be something positive which is distinct from the individual's specific difference. The subsequent questions, all answered in the negative, serve to demonstrate the inadequacy of the accounts of his predecessors and interlocutors, insofar as they seek to locate the principle of individuation in the already existing individual (3), some one of its accidental qualities (4), or in the inadequate hylomorphic concept of matter (5). In his critique of the possibility that matter can suffice to account for individuation, Scotus was motivated by a peculiar theological concern: for if matter individuated, it would be impossible that angels, which are supposed to be immaterial beings, could be distinct from one another, whereas there are scriptural references to multiple angels. But the consequences of his critique extend well beyond this esoteric interest.

1. The first possibility, that a thing is individual by virtue of its very nature, or 'from itself', is the position Scotus attributes to Roger Marston. ${ }^{6}$ This would mean that the very nature of a thing, or its specific difference, is that by virtue of which there are individuals of that species. However, this leads to the problematic contention that the nature of 'stoneness' is what accounts for the individual differences between this and that stone, whereas it seems clear that what two things have in common cannot be that by which they are distinguished from one another. ${ }^{7}$ Scotus argues that 'there is some real unity in the thing that is less-than-numerical unity or the proper unity of the singular. This unity belongs to the nature in itself' (Scotus 1987: Ordinatio II, Distinction 3, Part 1, Question 1, $\$ 30) .{ }^{8}$ In other words, that which is held in common is real, but its unity is 'less-than-numerical' insofar as it is insufficient on its own terms to constitute any this-it does not individuate on its own.

This common nature, as less-than-numerical, is nevertheless not incompatible with either universality, or else we would not be able to talk about what it is to be a stone, nor with individuality, since there are indeed individual stones. ${ }^{9}$ Consider that when we say, 'these two are both stones', we mean at once that 'these two are both stones', or really have something in common; and at the same time that 'these two are both stones', that is, they are nevertheless distinct from one another, or they are individuals. Universality and individuality, therefore, are both compatible with the nature insofar as it is common, but insofar as it is less-than-numerical it is neither universal nor individual on its 
own: 'although [the nature] never really exists without some of these [features], nevertheless of itself it is not any of them. Rather, [the nature] is naturally prior to all of these [features]' (Scotus 1987: Q1 \$32). The common nature is neither universal nor particular, neither singular nor plural; rather, it is prior to and compatible with receiving any of these determinations.

Scotus argues that we must be careful not to think that the nature is common insofar as we understand it, and singular insofar as it 'really is' out there in the world, which would simply repeat the nominalist position. This is inadequate because common natures are not abstractions:

Commonness is suitable to the nature outside the intellect, and likewise singularity: commonness is suitable to the nature from itself, while singularity is suitable to the nature through something in the nature that contracts [the nature]. But universality is not suitable to the thing from itself. And so I grant that a cause of universality should be looked for, [as maintained in n.6]. Nevertheless, no cause of commonness other than the nature itself need be looked for. Once commonness is postulated in the nature itself according to its proper beingness and unity, one must necessarily look for the cause of singularity, which adds something more to the nature to which it belongs. (Scotus 1987: Q1 \$32)

Scotus recognises, on the one hand, that insofar as we agree that something is held in common between individuals, it must be something real. But, on the other hand, and against the (Platonic) realists, he holds that it is in fact singulars which are 'ultimately actual', since only they, and not abstract universals, have numeric unity; this numeric unity is the 'something more' they add to the common nature. Hence when we say that the common nature has 'less-than-numeric unity', as Paolo Virno argues, this amounts to a 'realism of the Common and a nominalism of the Universal' (Virno 2009: 62). Now, based on this formulation of the common nature, we will need to ask the question of individuation anew: what is it that, as he puts it, 'contracts' (contrahens) the nature to individuality?

2. Scotus moves immediately to argue that this contracting factor must be something positive, contra Henry of Ghent, for whom individuation is the result of a twofold negation. According to the latter, an individual is not its species, and it is not any other individual of its species. On this account, "since "singularity" or "individuality" can only mean a double negation, it is not necessary to seek something positive as its cause, for the negation is sufficient' (Scotus 1987: Q2 \$44). However, 
Scotus asks, what do we mean when we say that something is an individual? We mean, above all else, that it cannot be divided into subjective parts: '[there is something] to which being divided into many parts of which any given one is that thing is formally incompatible' (Scotus 1987: Q2 \$48). While the species 'human' may be divided into members of that species, an individual human cannot be divided in this way without being destroyed. As Timothy B. Noone writes, for Scotus 'instantiability is contradictory with the notion of individuality as such' (Noone 2003: 114). The question is, by virtue of what is an individual incompatible with being divided? And as Scotus argues, the answer cannot be a negation or privation, but must be something positive: 'nothing is simply incompatible with some being through a privation in it alone, but rather through something positive in it' (Scotus 1987: Q2 $\$ 49$ ). Or again: 'No imperfection is formally incompatibility with something except through some perfection, ${ }^{10}$ (Scotus 1987: Q2 \$52). Individuality, or incompatibility with being divided, is in fact a positive feature of things, and thus cannot be explained by means of negation alone.

But even more directly, Scotus argues that this attempt in fact begs the question: 'I ask whence a negation is a this, since it is of the same account in this [singular] and in that one' (Scotus 1987: Q2 \$56). If the question is: 'by virtue of what is something a this?' then to answer: 'this negation' is obviously insufficient and circular. Clearly, it is true that individuals are not their species and not other individuals of that species; but these negative relationships are secondary effects of that which positively individuates them. ${ }^{11}$

3. In question 3, Scotus very quickly dismisses the idea that it is the act of existing that individuates or contracts the common nature. The suggestion is that whatever distinguishes something cannot be its potential being, but its actuality; but existing is 'the ultimate act of individuals', compared with which everything else about them is merely possible; and thus this very act of existing, esse existentiae, is that which distinguishes or individuates the common nature (Scotus 1987: Q3 \$60). Scotus objects to this, first, that whatever distinguishes or determines individuals must itself be distinct and determinate, but 'the act of existing' is neither of these things; in fact, 'that it exists' seems to be about as indeterminate a claim as can be made about something (Scotus 1987: Q3 \$\$61-2). And second, he repeats the argument from $\$ 56$ above, since 'it can be asked through what the existence is a this' (Scotus 1987: Q3 \$64). Simply put, 'this existence' is again circular and insufficient as an answer to the question of what makes something a this. 
4. Scotus turns then to the position that it is matter, and material quantity, that individuates. This seems minimally plausible as an account of individuation given a hylomorphic model in which an individual's form is distinct from its matter: since ostensibly the formal cause is identical in the case of two individuals-for example, universal 'humanity' would be the same for any two humans - then perhaps it is the material cause, or the relationship between the form and its matter, which provides the principle of individual difference. Scotus quotes Boethius: 'The variety of accidents produces difference in number, for three men differ neither in species nor in genus, but in their accidents' (Scotus 1987: Q4 \$67). We can therefore also formulate this suggestion as follows: two members of a species are the same in essence; but they are not identical insofar as they are individuals with different accidental qualities; thus it must be their accidental qualities that individuates them. But Scotus argues that this attempt also fails, for the simple reason that an individual substance is prior-by nature and by definition - to its accidents, and it is absurd to argue that anything can cause what precedes it: 'no accident can per se be an account through which material substance is individuated' (Scotus 1987: Q4 \$76). Thus, the lesson here is that the principium individuationis cannot be found among any individual's accidental characteristics, and in particular the quantity of material that an individual possesses falls unambiguously into this category.

Moreover, if we understand by a substance something that is logically prior to its accidents, then we must similarly reject the idea that it is the composite of substance and its accidents which individuates the former, since any such aggregate would itself have to be accidental (Noone 2003: 115). Simply on the basis of the logical priority of material substantial individuality to its accidents, Scotus concludes that 'it is impossible for a substance to be individual through some accident' (Scotus 1987: Q4 $\$ 111)$. We can also put this in the now-familiar terms of the charge of circularity: we presuppose its being a this when we say that this quantity of material can be that through which something is individuated (Scotus 1987: QQ5-6 \$138).

Even the apparently more sophisticated suggestion, namely that the individuating difference is the relationship between a thing's form and matter, fails for the same reason. Given that the form, ex hypothesi, is identical in the case of two members of a species, the difference in the relationships between their forms and the matter that together constitute them will turn out to be nothing other than the difference in their matter. For there are only two terms in this relationship, the form and the matter; 
and so if, when we compare two such composites, one of the terms is identical in both, then the difference between these two composites will be entirely dependent on the second term, in this case matter. ${ }^{12}$

5. But there is another way in which this hylomorphic approach cannot account for individuation by material difference. In the third question, Scotus did not object to the idea that individuals must be distinguished by their actuality rather than by their potentiality; he objected rather to the suggestion that the simple act of existence can suffice to account for individuation. Indeed, given two things that are actually identical but which could potentially be different, we have no way to distinguish between them. But on the hylomorphic account, matter is taken to be the principle of pure potentiality or dynamis. How, then, would it be possible for a differential distribution of potentialities to account for actual individuation? As Noone puts it, 'positing matter as the principle of individuation seems to entail locating the source of the greatest unity (unitas maxima) and actuality in a principle that is ordinarily the source of multiplicity and potentiality' (Noone 2003: 117). For this reason, matter is not capable of furnishing us with a principle of individuation: the pure capacity to receive a form cannot be a positive factor that contracts a common nature into singularity.

This distinguishing or contracting positive factor cannot be an essential, specific, or 'quidditative' distinction, since this would entail a difference at the level of the common nature and not at the level of the individual:

the singular is not definable by some definition other than the definition of the species. The [singular] is nevertheless per se a being, adding some beingness to the specific beingness. However, the per se beingness that [the singular] adds [to the specific beingness] is not quidditative beingness. (Scotus 1987: QQ5-6 $\$ 192)$

Thus there is no science of the singular. If we ask after the quidditative being or essence of an individual, we must conclude that it is its specific difference; however, it is also the case that the individual adds something to the common nature that it contracts. As Virno argues, this yields the surprising, even paradoxical conclusion that the individual is both 'more' and 'less' than the species: the individual adds something to the common nature and, in contracting it, gives it the mode of ultimate existence or actuality; however, the common nature is never exhausted by the singular into which it is contracted (Virno 2009: 63-4). And one immediate consequence of this analysis, as we suggested at the outset, is that the common nature is not thinkable as indifferent, even though it 
is logically pre-individual. That is, the positive contracting factor is not the only positivity at play in differentiation: the common nature, too, is positive and determinate, although on its own it is neither singular nor universal. This pre-individual determinacy is what Deleuze, in Difference and Repetition, calls the 'virtual', and it is to his investigation that we will now turn.

\section{Deleuze and the Distinctness of the Virtual}

The concept of the virtual occupies a vexing position in the reception of Deleuze's thought. On the one hand, it is quite obvious, at least in Difference and Repetition, that the virtual plays a central role in his metaphysics; on the other hand, any survey of the secondary literature will more likely than not leave the reader confused as to what precisely this role is. For instance, Žižek, in his monograph on Deleuze, writes that we must be careful not to conflate it with the 'virtual reality' of a digital world before attempting to reformulate it using his familiar Lacanian vocabulary, in which he somewhat confusingly claims both that it 'as such is the Real', but also that it is the 'symbolic as such' (Žižek 2012: 3-4). Moreover, he suggests that we understand by it a kind of 'quantum oscillation', and that the virtual names an ineliminable excess of becoming over being (Žižek 2012: 8-10, 21). On the other hand, Badiou, in his own monograph Deleuze: The Clamor of Being, argues that the virtual is the 'name of Being', 'the very Being of beings', ultimately suggesting that the virtual is an idealist Platonic hangover in Deleuze's thought, the postulate of a transcendent One-All that results from his inadequate reckoning with the implications of post-Cantorian mathematics (Badiou 2000: 43, 48). Even more sympathetic readings of Deleuze are often misleading and contradictory. Brian Massumi claims that the virtual names the "real but abstract" incorporeality of the body' (Massumi 2002: 19-21), arguing that certain fashionable forms of contemporary social critique are not abstract enough; he tends to characterise it as a kind of total space of incompossible and unliveable coexistences whose affective relation to the actual is, apparently, the object of quantum physics. ${ }^{13}$ It seems difficult to accept this characterisation of the virtual as 'real but abstract', given that Deleuze cites Proust as having articulated its formula: the virtual is, he says, 'real without being actual, ideal without being abstract' (Deleuze 1994: 208).

For our part, we would like to suggest that it is within the context of the problem of individuation, which we have been exploring in Duns 
Scotus, that the concept of the virtual gains its sense and becomes intelligible. The theory of the virtual, as we will show, is Deleuze's response to the question of how and in what way the pre-individual real, like Scotus' common nature, is anything but indistinct. Rather than the abyss of undifferentiated (in)difference, the virtual is completely determined, in a way that is 'distinct and obscure'.

Just as Scotus reached the postulate of a common nature essentially prior to and compatible with both individuality and universality, Deleuze argues that we can grasp the virtual only on condition that we think it as pure past: 'The virtual object is not a former present', which would be the thought of a relative past, a past thought only in relation to the contracted present; rather, it is 'the past as contemporaneous with its own present, as pre-existing the passing present and as that which causes the present to pass' (Deleuze 1994: 101). The virtual is thus what is 'behind' the actual, in two senses: it is behind logically and temporally, as that which has been actualised; but moreover, it is what is behind the contraction of the present, as what causes it. Indeed, the contemporaneity of the virtual past in relation to the actual present is a consequence of the former being the cause of the latter. Here already at the level of language, we can begin to see the connection between the problem of individuation in both Scotus and Deleuze: the virtual is that by virtue of which the present is contracted into actual states populated by distributions of individuals.

It is in the fourth chapter of Difference and Repetition, entitled 'Ideal Synthesis of Difference', that Deleuze attempts to work out the logic of this virtual contraction. ${ }^{14}$ Claiming to find in Kant a theory of Ideas as being essentially problematic, and in this way objective, he argues that they 'present three moments: undetermined with regard to their objects, determinable with regard to objects of experience, and having an ideal of infinite determination with regard to concepts of the understanding' (Deleuze 1994: 169). The plausibility of his theory of Ideas will turn on whether or not he is able to demonstrate intrinsic and necessary connections between these three modalities of determination, which are the key moments of his theory of differentiation: the undetermined, the determinable, and the completely or infinitely determined. In order to elaborate these connections, he turns immediately to the differential calculus and proposes a novel interpretation.

Now although he identifies Kant as the terminal point of a sequence beginning with Plato and passing through Leibniz in the development of the theory of Ideas, Deleuze's own project clearly and radically breaks from Kantian philosophy on this score. The inadequacy of 
transcendental idealism, from Deleuze's perspective, is most acutely articulated in the early critiques of Salomon Maïmon in his Essay on Transcendental Philosophy: it is necessary to pass from a theory of extrinsic conditions to one of intrinsic genesis. From the point of view of transcendental conditions alone, the relationship between the determinable and the determined remains totally extrinsic: if the condition for the possibility of any representation is the pure forms of intuition, this tells us nothing about this representation - not only does it tell us nothing about what it is in its particularity, but we have no way of grasping why we have this one and not another. ${ }^{15}$ Deleuze considers Kant's introduction of the schematism to be evidence of this inadequacy, through which 'difference remains external and as such empirical and impure, suspended outside the construction "between" the determinable intuition and the determinant concept' (Deleuze 1994: 173-4). Hence if we are to develop a theory of individuation, it cannot be grounded upon a system of extrinsic conditions. The theory of conditions is necessarily formal, but the genetic problem of individuation or differentiation, as we saw with Scotus, is one that cannot be resolved by formal or extrinsic accounts. Surely it is necessary that individual substances have matter (angels notwithstanding), but in any event the fact of having matter is not sufficient for their individuation.

For Deleuze, every individual is the actual solution or resolution of a virtual problem. As Dan Smith argues, it is false, or at least inadequate, to consider Deleuze an anti-dialectical thinker; rather, he proposes a new concept of dialectics (Smith 2006: 147). Deleuze writes:

Problems are always dialectical: the dialectic has no other sense, nor do problems have any other sense ... it must be said that there are mathematical, physical, biological, psychical and sociological problems, even though every problem is dialectical and there are no non-dialectical problems. (Deleuze 1994: 179)

Dialectics is the art of problems, or of problematic Ideas; and as an art, it is compelled in its movement no less than science by a strict necessity - in fact, by a principle of sufficient reason. In his lectures on Leibniz, Deleuze argues that the difference between cause and reason comes down, once again, to the distinction between condition and genesis, or between extrinsic and intrinsic relations of determination:

Cause is never sufficient. One must say that the principle of causality poses a necessary cause, but never a sufficient one. We must distinguish between necessary cause and sufficient reason ... sufficient reason expresses the 
relation of a thing with its own notion, whereas cause expresses the relation of the thing with something else. (Deleuze 1980)

The 'problematic', which Deleuze defines as the 'ensemble of the problem and its conditions', is a virtual multiplicity in which the relations between the undetermined, determinable, and completely determined particular to it are intrinsic, thus constituting a principle of sufficient reason.

Differential calculus, according to Deleuze, provides a model for such a problematic or dialectical Idea-although it does not constitute an archetype or analogy, and it does not even express the exclusive formulation of the mathematical Idea. It is a question of exhibiting the necessary moments of the process of differentiation which constitute its sufficient reason:

The symbol $d x$ appears as simultaneously undetermined, determinable and determination. Three principles which together form a sufficient reason correspond to these three aspects: a principle of determinability corresponds to the undetermined as such $(d y, d x)$; a principle of reciprocal determination corresponds to the reciprocally determinable $\left(\frac{d y}{d x}\right)$; a principle of complete determination corresponds to the effectively determined (values of $\frac{d y}{d x}$ ). In short, $d x$ is the Idea - the Platonic, Leibnizian or Kantian Idea, the 'problem' and its being. (Deleuze 1994: 177)

For a given function $f(x), d x$ represents the 'rate of change' of the $x$ value. In relation to $x$ alone, $d x$ is completely undetermined-nothing about the $x$ value indicates anything about the rate at which the value changes, and at any given point $d x$ literally does not exist; and the same holds for $d y$ solely in relation to $y$. However, 'they are perfectly determinable in relation to one another. For this reason, a principle of determinability corresponds to the undetermined as such' (Deleuze 1994: 171). As Hegel noted in the wonderful Remark on infinite quantity in the Science of Logic, in the differential $\frac{d y}{d x}$ the two terms are only 'moments' of a process, and have sense as determinable only in relation to one another (Hegel 2010: 215; cf. Deleuze 2006: 182). Deleuze argues therefore that the principle of reciprocal determinability is not extrinsic to, but is entailed by, the very nature of the undetermined.

Moreover, in this passage from the undetermined to reciprocal determination, according to Deleuze, we have also passed from quantitability to qualitability. Leibniz's method for finding the derivative invoked 'infinitesimals', infinitely small quantities, which traverse an ideal distance and at the limit vanish entirely, such that, based on his principle of the identity of indiscernibles, the secant becomes identical 
to the tangent (Leibniz 1989: 545-6). Although this approach yielded consistent and accurate results experimentally, until the middle of the nineteenth century it was considered methodologically illegitimate; much of the controversy about the legitimacy of these methods came down to a concern over the validity of mathematical concepts derived from geometric intuition, and in particular about the geometric intuitions of continuous spatial magnitudes and their infinite divisibility (Boyer 1959: 190-6, 224-9). Marx, in his mathematical manuscripts, even refers to this as the 'mystical' variant of the differential calculus, whose procedures were not justified by rigorous mathematics but were rather accepted because the experimental results were known in advance (Marx 1983: 3, 91-4). While Deleuze is similarly sceptical about geometric intuition, unlike mathematicians such as Cauchy and Weierstrass, who sought to eliminate any trace of these concepts from mathematics, he nevertheless seeks to retain the concept of continuousness as 'the pure element of quantitability, which must be distinguished both from the fixed quantities of intuition [quantum] and from variable quantities in the form of concepts of the understanding [quantitas]' (Deleuze 1994: 171). Reversing the classical order, he argues that this continuity is grounded by, rather than grounding, the limit as a 'genuine cut [coupure], a border between the changeable and the unchangeable within the function itself' (Deleuze 1994: 172).

When we find the derivative of a function $f(x)$, we obtain a new function: $\frac{d y}{d x} f(x)$ or $f^{\prime}(x)$. But between these two functions there is a difference which is no longer simply quantitative, but rather qualitative, insofar as the functions necessarily have different powers. Here again Deleuze's analysis echoes that of Hegel, who also argued that the reciprocal relation of $d y / d x$ has an essentially qualitative, rather than simply quantitative, character (Hegel 2010: 215-28). That is, for example, there is a qualitative difference between the curve described by a polynomial function with a power of 2 and the straight line of its derivative. This is the sense in which Deleuze writes that the differential relation is determinable in a qualitative form. In the example we have just given, as with any such example, 'in so far as it expresses another quality, the differential relation remains tied to the individual values or to the quantitative variations corresponding to that quantity' (Deleuze 1994: 172). However, if we attend to the universal logic of the differential determination, rather than the particular qualitative difference exhibited in the example, we discern in this transformation 'a pure element of qualitability' that derives from the principle of reciprocal determination (Deleuze 1994: 173). 


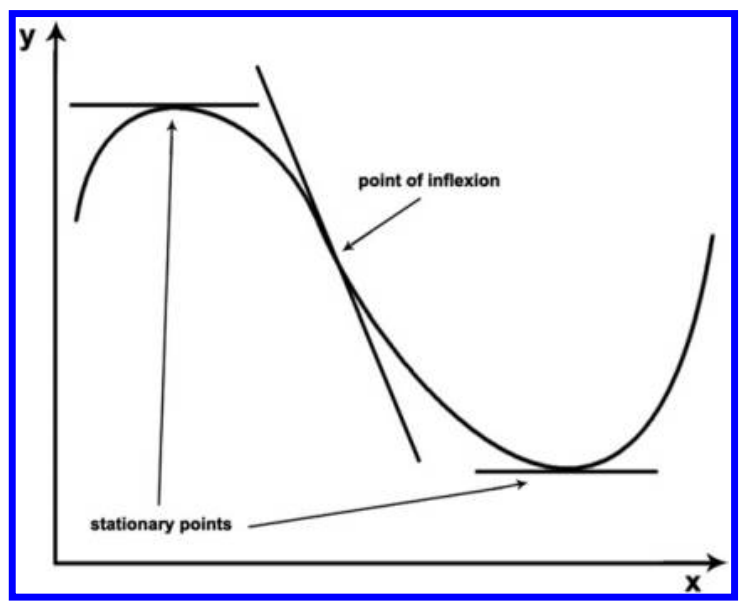

Figure 1. Singular points on continuous curves. (Source: Reproduced with permission fromn Simon Duffy (2006) 'The Mathematics of Deleuze's Differential Logic and Metaphysics', in Simon Duffy (ed.), Virtual Mathematics: The Logic of Difference, Manchester: Clinamen Press, p. 128.)

The qualitative difference here is, as we said, one of powers; and it is in this way, Deleuze argues, that we move from the second principle to the third:

the differential relation presents a third element, that of pure potentiality. Power is the form of reciprocal determination according to which variable magnitudes are taken to be functions of one another ... A principle of complete determination corresponds to this element of potentiality. (Deleuze 1994: 174-5)

To every power, there corresponds a distribution of singular points which are completely determined. Simon Duffy offers an illuminating diagram illustrating what is meant by 'singular point' in this context (Figure 1). ${ }^{16}$

Singular points, as he writes, are:

points of articulation where the nature of the curve changes or the function alters its behaviour ... The differential relation characterises or qualifies not only the distinctive points which it determines, but also the nature of the regular points in the immediate neighbourhood of these points. (Duffy 2006: 128)

If we were to take the derivative of the function graphically represented here, we would obtain a new function with a lower power describing a 
parabola, in which the 'stationary points' would become the points at which the curve passes through the $x$-axis $\left(f^{\prime}(x)=0\right)$, and the 'point of inflection' would become the parabola's nadir $\left(f^{\prime \prime}(x)=0\right)$.

The singular points on their own do not yet constitute the function-they are not the principium individuationis, although they provide the coordinates within which the function's individuation occurs. It is the distribution of these singular points that is the object of the principle of complete determination (Deleuze 1994: 175). The differential establishes not only the singular points, but also how they involve 'neighbourhoods' within which the ideal infinite continuity is quantitatively determined. In other words, each completely determined pre-individual singular point ranges over an infinity of ordinary points within its area of influence: 'a series of powers with numerical coefficients surround one singular point, and only one at a time' (Deleuze 1994: 176). As Dan Smith writes, in this way we obtain a definition of the individual: 'one can say of any determination in general (any "thing") that it is a combination of the singular and the ordinary: that is, it is a "multiplicity" constituted by its singular and ordinary points' (Smith 2012: 56).

It is here, finally, that we return directly to our question about individuation: the completely determined distribution of such singular points, as fully real but pre-individual and only actualised through infinite variations at the level of individual differences, is precisely the way in which the virtual is not undifferentiated: this constitutes 'the distinctness of Ideas' (Deleuze 1994: 176). Deleuze thus develops the notion of 'different/ciation': 'We call determination of the virtual content of an Idea differentiation; we call the actualization of that virtuality into species and distinguished parts differenciation' (Deleuze 1994: 207). As in Scotus' renewal of the problem of individuation, all the difficulty lies in evading the Scylla of affirming actuality (Platonic realism), and the Charybdis of denying reality (nominalism), when it comes to the virtual or the common nature. For in both cases, we are indeed considering something real: 'The reality of the virtual consists in the differential elements and relations along with the singular points which correspond to them ... far from being undetermined, the virtual is completely determined' (Deleuze 1994: 209). This is the sense in which, as Deleuze argues, the undetermined of the problematic Idea is nevertheless objectively real, and non-knowledge is transformed not into an absence but into the positivity of what is to be thought. 


\section{Conclusion}

More than a shared affirmation of the 'univocity of being' (Deleuze 1994: 35-40), it is the discovery of and rigorous insistence upon the objective reality and positivity of the undetermined, of the preindividual, that constitutes the thread uniting Deleuze and Scotus in their efforts to think through the problematic of individuation. As Deleuze writes, the virtual or the Idea is that which must be understood both as distinct, as the completely determined distribution of singular points (differentiated); and also as obscure, as not yet actualised or distinguishable as individuals are (undifferenciated). In this sense, preindividual singularities and their distribution possess, as Scotus would say, a less-than-numeric unity. In describing distinctness-obscurity, Deleuze likes to refer to Leibniz's notion of petites perceptions: the sound of a crashing wave that one hears is actually constituted by an infinite multiplicity of minute perceptions, a cacophony integrating the collision of each and every drop of water, of which one is unconscious and which one is entirely incapable of distinguishing clearly (Deleuze 1994: 213; Leibniz 1996: 54-7). The astonishing thing is that these indistinguishable infinitesimals might be contracted into an individual - that somehow less-than-numeric unity or pre-individual reality is occasionally actualised. But the astonishing character of this integration or contraction should force us to ask after the individual's sufficient reason, not to posit an abstract possibility of its contingent existence. With this insight, that of the determinacy of problematics, the very questions of metaphysics are transformed: no longer 'what is this?' but 'why this one?' and even 'why this now?' (Deleuze 2004; Lampert 2011: 1-11, 114-70). And on the basis of this insight and these transformations, dispensing with the illusion of abstract possibility, philosophy teaches us to ask after the conditions of intervention not at the level of actual determinations, but at the virtual level of preindividual distributions. For just like all of Scotus' rejected candidates for what could constitute the principle of individuation, attempts to intervene at the level of the already actual always come too late on the scene.

\section{Notes}

1. It may be helpful to explain at the outset why our analysis does not focus on Deleuze's usage of the concept of haecceity, which he obviously adapts directly from Scotus. Scotus develops the notion of haecceitas or 'thisness' precisely in the investigation into the problem of individuation that we explore; a singular 
being's haecceity is, for Scotus, that positive but indeterminable difference, what distinguishes it from others but which is nevertheless irreducible to any particular quality or set of qualities (qualitas or quidditas), since it must be prior to these. By contrast, when Deleuze uses the language of haecceity, he explicitly uses it to designate the problem not of individual differentiation but of impersonal singularisation; that is, he pushes the concept decisively beyond the limits determined by Scotus' usage of it, and attempting to compare these deployments risks confusing the matter and obscuring Deleuze's philosophical novelty. Deleuze's own formulations make this clear. In A Thousand Plateaus, haecceity names the kind of spatiotemporal individuation proper to concrete assemblages and affective durations: 'There is a mode of individuation very different from that of a person, subject, thing, or substance. We reserve the name haecceity for it' (Deleuze and Guattari 1987: 261; cf. 260-77, 506-8). But of course, the kind of individuation that Scotus is interested in is precisely that of persons, subjects, things or substances. Or again, Deleuze writes: 'The life of the individual gives way to an impersonal and yet singular life that releases a pure event freed from the accidents of internal and external life ... It is a haecceity no longer of individuation but of singularization: a life of pure immanence... The life of such individuality fades away in favour of the singular life immanent to a man who no longer has a name, though he can be mistaken for no other. A singular essence, a life ...' (Deleuze 2001: 28-9). Suffice it to say that the concept of haecceitas here is not Scotus', and it is not clear that Scotus would even recognise his monstrous Deleuzian progeny in these lines. Thus Zourabichvili notes that 'Scotus conceived haecceity as an individuation of form, whereas Deleuze thinks it as an intensive and evental individuation, as mobile and communicating' (Zourabichvili 2012: 127).

2. It might be objected that in later works, such as The Fold, Deleuze walks back this hostility to the category of the possible. However, his reading of Leibniz's 'best of all possible worlds' undermines this objection: 'Leibniz in no way reintroduces a duality that would turn our relative world into the reflection of a more profound, absolute world; to the contrary, he turns our relative world into the only existing world, a world that rejects all other possible worlds because it is relatively "the best"' (Deleuze 2006: 68). In other words, Deleuze sees in Leibniz's concept of incompossibility a critical repudiation of the abstract or negative concept of indifferent possibility. In fact, this is because, just like in the case of the virtual, the relation of incompossibility is not simply negative, and instead involves a complex of positive differences, a completely determined distribution of singular points: 'it seems to us that the incompossible is an original relation in Leibniz, irreducible to any form of contradiction. It is a difference and not a negation' (Deleuze 2006: 174).

3. Similar notions can be found in the work of Gilbert Simondon, who with his concept of 'metastable states' as determinate but pre-individual systems 'suffused with potentials' clearly influenced Deleuze; and Manuel DeLanda, whose Deleuzian approach to the philosophy of science invokes 'phase spaces' and 'cascading bifurcations' in describing processes of individuation (Simondon 1992; DeLanda 2002). Miguel de Beistegui, John Protevi and Alberto Toscano have all contributed substantially to research on Deleuze's relationship to the philosophy and history of the problem of individuation (cf. de Beistegui 2004; Protevi 2006; Toscano 2006).

4. For example, Spinoza writes in the Preface to Part IV of the Ethics: 'the eternal and infinite being, whom we call God, or nature, acts by the same necessity by which it exists' (Spinoza 2002: 321). For a thoughtful discussion of this rhetorical tactic in Spinoza and contemporary philosophers following in his 
footsteps, see Montag's Althusser and His Contemporaries (Montag 2013: 116). Regarding Deleuze's concept of inclusive disjunction or the immanent affirmation of difference, see the Twenty-Fourth Series of the Communication of Events and the Twenty-Fifth on Univocity in The Logic of Sense, and the critique of exclusive disjunction as illegitimate or transcendent in Anti-Oedipus (Deleuze 1990: 172-80; Deleuze and Guattari 2003: 75-84).

5. On the literality of Deleuze's concepts, their non-metaphoric character, Zourabichvili's work is particularly instructive: literality is 'entirely a question of the intrinsic or extrinsic nature of the relation between the actual and the virtual: the representation of a scene versus the trace of a becoming ... Far from extolling an obtuse fixation on the literal usage of words, commitment to literality takes us prior to the distinction between the literal and the figurative - the plane of immanence or of univocity, where discourse, prey to its becomings, has little to fear from the "sedentary" minds who take it to be metaphor' (Zourabichvili 2012: 162). See also his essays on literality and Deleuze's philosophy in La Litteralité et autres essais sur l'art (Zourabichvili 2011).

6. Here and in what follows, we are not particularly concerned with whether Scotus is accurate or fair in how he presents the positions of his interlocutors, such as Roger Marston and Henry of Ghent; even if he happens to misrepresent them, our interest lies in the logic of Scotus' own arguments.

7. This is the same argument that Spinoza makes in Proposition 5 of the first book of the Ethics, according to which there cannot be more than one substance with a given attribute. For if an attribute is what the intellect perceives as constituting the essence of a thing, and we say that two things are distinct insofar as they have the same attribute, then we are claiming that we distinguish them from one another by virtue of the essence they have in common, which is impossible (Spinoza 2002: 217-18).

8. Every reference to Scotus in what follows will be from this First Part of Distinction 3 of Book II of the Ordinatio, and thus will be cited by Question and Paragraph number.

9. The logic of this objection is very close to those raised by Malebranche's fictional interlocutor Aristes in his Dialogues on Metaphysics and on Religion, regarding the conditions for the possibility of generalising concepts, in Dialogues I and II (Malebranche 1997: 3-30).

10. Again the parallels here with Spinoza are striking. For Spinoza as for Scotus, negation is insufficient to account for the positive qualities of any given thing. See, for instance, Ethics I Axiom 3; I P4; I P26-28; III P4-8, etc. For this reason, we would argue that Hegel's influential interpretation of Spinozism in the Science of Logic (Hegel 2010: 61, 74, 87) and the Lectures on the History of Philosophy (Hegel 1990: 151-64) turns on a problematic misreading of 'omnis determinatio est negatio'. On this point we follow Macherey, in particular chapters 1 and 4 of Hegel or Spinoza (Macherey 2011).

11. Deleuze says almost the exact same thing in criticising the Hegelian theory of the primacy of the negative: 'It is of the essence of affirmation to be in itself multiple and to affirm difference. As for the negative, this is only the shadow cast upon the affirmations produced by a problem: negation appears alongside affirmation like a powerless double, albeit one which testifies to the existence of another power, that of the effective and persistent problem' (Deleuze 1994: 267).

12. Scotus' beautiful critique of this 'relational' position amounts to demonstrating that it is not relational at all, since one of the terms of the relation is completely static, and so what was supposed to have been a dynamism is anything but. Following the same logic, we will come to see, according to Deleuze, that it is not enough to relate $d x$ to $x$, or $d y$ to $y$; in these relations the differentials 
are completely undetermined, since $x$ and $y$ are algebraic symbols representing values that are actually only indifferently determinate; that is, $x$ and $y$ are, in principle, constants. It is only when we relate the two dynamic variables, $d x$ and $d y$, that we find that they are reciprocally determinable $(d x / d y)$, and this relation is completely determined when its power is conditioned by a distribution of singular points $d x / d y=f^{\prime}(x)$ Deleuze 1994: 172-6).

13. Žižek and Massumi are hardly alone in referring to quantum physics in discussing Deleuze's metaphysics; it has become something of a mainstay in the genre. Such references are often confusing when not confused. Here as elsewhere Žižek follows the so-called 'Copenhagen interpretation' of quantum physics, which is by no means the only one, even if it enjoys a hegemonic status today. But even in terms of this particular interpretation, his presentation is somewhat misleading; for instance, in his book on Schelling, he suggests that Werner Heisenberg's uncertainty principle is what Niels Bohr's complementarity 'is all about' (Žižek 2007: 208-13), when in fact uncertainty and complementarity are competing, incompatible interpretations, and Heisenberg ultimately retracted his position, ceding to Bohr. For a recent critical analysis of Žižek's interpretation and mobilisation of quantum physics in elaborating his Hegelian-Lacanian ontology, see chapter 7 of Adrian Johnston's Adventures in Transcendental Materialism (Johnston 2014: 165-83). For helpful and philosophically robust introductions to quantum physics and its history, see Feynman 2014; Omnès 1999; Stengers 2010: 3-101; Barad 2007; Prigogine 1980. For a rigorous and informed polemic against the hegemony of the Copenhagen indeterminist interpretation in favour of a Bohmian determinist one, see Dürr et al., Quantum Physics without Quantum Philosophy: 'Bohmian mechanics is a version of quantum mechanics that, while expressed in precise mathematical terms, is clear as physics. Why isn't it taught? ... one of the fundamental reasons for the dismissal seems to be this: Bohmian mechanics is against the spirit of quantum mechanics. That is, an objective physical description, a return to determinism, a return to physical clarity clash with the tenets of quantum philosophy' (Dürr et al. 2013: 9). For a particularly lucid discussion of the role of quantum field theory in Deleuzian philosophy, see Plotnitsky 2006.

14. Translation modified. In the English translation the chapter is entitled 'Ideas and the Synthesis of Difference'; in the original, Deleuze writes 'Synthèse idéelle de la différence'.

15. See also Deleuze's remarks on the event as concrete individuation in The Fold: 'Matter, or what fills space and time, offers characters that always determine its texture as a function of different materials that are part of it. No longer are these extensions but, as we have seen, intensions, intensities, or degrees. It is something rather than nothing, but also this rather than that: no longer the indefinite article, but the demonstrative pronoun' (Deleuze 2006: 87-8).

16. We are very grateful to Simon Duffy for granting permission to reprint this diagram.

\section{References}

Badiou, Alain (2000) Deleuze: The Clamor of Being, trans. Louise Burchill, Minneapolis: University of Minnesota Press.

Barad, Karen (2007) Meeting the Universe Halfway: Quantum Mechanics and the Entanglement of Matter and Meaning, Durham, NC: Duke University Press.

Boyer, Carl B. (1959) The History of the Calculus and Its Conceptual Development, New York: Dover Publications. 
de Beistegui, Miguel (2004) Truth and Genesis: Philosophy as Differential Ontology, Bloomington: Indiana University Press.

DeLanda, Manuel (2002) Intensive Science and Virtual Philosophy, New York: Continuum.

Deleuze, Gilles (1980) 'Lecture on Leibniz, April 15', trans. Charles J. Stivale, Les Cours de Gilles Deleuze, Webdeleuze, available at < https://www.webdeleuze. com/textes $/ 50>$ (accessed 12 April 2018).

Deleuze, Gilles (1990) The Logic of Sense, trans. Mark Lester with Charles Stivale, ed. Constantin V. Boundas, New York: Columbia University Press.

Deleuze, Gilles (1994) Difference and Repetition, trans. Paul Patton, New York: Columbia University Press.

Deleuze, Gilles (2001) Pure Immanence: Essays on A Life, trans. Anne Boyman, New York: Zone Books.

Deleuze, Gilles (2004) 'The Method of Dramatization', Desert Islands and Other Texts, 1953-1974, ed. David Lapoujade, trans. Michael Taormina, New York: Semiotext(e), pp. 94-116.

Deleuze, Gilles (2006) The Fold: Leibniz and the Baroque, trans. Tom Conley, New York: Continuum.

Deleuze, Gilles and Félix Guattari (1987) A Thousand Plateaus: Capitalism and Schizophrenia, trans. Brian Massumi, Minneapolis: University of Minnesota Press.

Deleuze, Gilles and Félix Guattari (2003) Anti-Oedipus: Capitalism and Schizophrenia, trans. Robert Hurley, Mark Seem and Helen R. Lane, Minneapolis: University of Minnesota Press.

Duffy, Simon (2006) 'The Mathematics of Deleuze's Differential Logic and Metaphysics', in Simon Duffy (ed.), Virtual Mathematics: The Logic of Difference, Bolton: Clinamen Press, pp. 118-44.

Dürr, Detlef, Sheldon Goldstein and Nino Zanghì (2013) Quantum Physics without Quantum Philosophy, New York: Springer.

Feynman, Richard P. (2014) QED: The Strange Theory of Light and Matter, Princeton, NJ: Princeton University Press.

Hegel, G. W. F. (1990) Lectures on the History of Philosophy, The Lectures of 1825-1826. Volume III: Medieval and Modern Philosophy, ed. Robert F. Brown, trans. R. F. Brown and J. M. Stewart with the assistance of H. S. Harris, Berkeley and Los Angeles: University of California Press.

Hegel, G. W. F. (2004) Phenomenology of Spirit, trans. A. V. Miller, New York: Oxford University Press.

Hegel, G. W. F. (2010) Science of Logic, ed. and trans. George di Giovanni, New York: Cambridge University Press.

Johnston, Adrian (2014) Adventures in Transcendental Materialism: Dialogues with Contemporary Figures, Edinburgh: Edinburgh University Press.

Lampert, Jay (2011) Deleuze and Guattari's Philosophy of History, New York: Continuum.

Leibniz, Gottfried Wilhelm (1989) 'Justification of the Infinitesimal Calculus by That of Ordinary Algebra', Philosophical Papers and Letters, 2nd edn, ed. and trans. Leroy E. Loemker, Boston: Kluwer Academic, pp. 545-6.

Leibniz, Gottfried Wilhelm (1996) New Essays on Human Understanding, ed. and trans. Peter Remnant and Jonathan Bennett, New York: Cambridge University Press.

Macherey, Pierre (2011) Hegel or Spinoza, trans. Susan Ruddick, Minneapolis: University of Minnesota Press.

Malebranche, Nicolas (1997) Dialogues on Metaphysics and on Religion, ed. Nicholas Jolley and David Scott, trans. David Scott, New York: Cambridge University Press. 
Marx, Karl (1983) Mathematical Manuscripts of Karl Marx, London: New Park Publications.

Massumi, Brian (2002) Parables for the Virtual: Movement, Affect, Sensation, Durham, NC: Duke University Press.

Montag, Warren (2013) Althusser and His Contemporaries: Philosophy's Perpetual War, Durham, NC: Duke University Press.

Noone, Timothy B. (2003) 'Universals and Individuation', in Thomas Williams (ed.), The Cambridge Companion to Duns Scotus, New York: Cambridge University Press, pp. 100-28.

Omnès, Roland (1999) Quantum Philosophy: Understanding and Interpreting Contemporary Science, trans. Arturo Sangalli, Princeton, NJ: Princeton University Press.

Peden, Knox (2014) Spinoza Contra Phenomenology: French Rationalism from Cavaillès to Deleuze, Stanford: Stanford University Press.

Plotnitsky, Arkady (2006) 'Chaosmologies: Quantum Field Theory, Chaos and Thought in Deleuze and Guattari's What is Philosophy?', Paragraph, 29:2, pp. 40-56.

Prigogine, Ilya (1980) From Being to Becoming: Time and Complexity in the Physical Sciences, New York: W. H. Freeman.

Protevi, John (2006) 'Deleuze, Guattari and Emergence', Paragrath, 29:2, pp. 19-39.

Scotus, John Duns (1987) Treatise on the Common Nature and Individuation (Ordinatio II, Distinction 3, Part 1, Questions 1-6), trans. Peter King, 'Editions and Translations', Peter King's Website, available at $<$ http://individual. utoronto.ca/pking/editions_and_translations.html > (accessed 12 April 2018).

Simondon, Gilbert (1992) 'The Genesis of the Individual', trans. Mark Cohen and Sanford Kwinter, in Jonathan Crary and Sanford Kwinter (eds), Zone 6: Incorporations, New York: Zone Books, pp. 297-319.

Smith, Daniel (2006) 'Axiomatics and Problematics', in Simon Duffy (ed.), Virtual Mathematics: The Logic of Difference, Bolton: Clinamen Press.

Smith, Daniel (2012) Essays on Deleuze, Edinburgh: Edinburgh University Press.

Spinoza, Baruch (2002) Ethics, in Spinoza: Complete Works, ed. Michael L. Morgan, trans. Samuel Shirley, Indianapolis: Hackett Publishing.

Stengers, Isabelle (2011) Cosmopolitics II, trans. Robert Bononno, Minneapolis: University of Minnesota Press.

Toscano, Alberto (2006) The Theatre of Production: Philosophy and Individuation between Kant and Deleuze, New York: Palgrave Macmillan.

Virno, Paolo (2009) 'Angels and the General Intellect: Individuation in Duns Scotus and Gilbert Simondon', trans. Nick Heron, Parrhesia, 7, pp. 58-67.

Žižek, Slavoj (2007) The Indivisible Remainder, New York: Verso.

Žižek, Slavoj (2012) Organs without Bodies: On Deleuze and Consequences, New York: Routledge.

Zourabichvili, François (1998) 'Deleuze et le possible (de l'involontarisme en politique)', in Gilles Deleuze. Une vie philosophique, ed. Éric Alliez, Paris: Institut Synthélabo, pp. 335-57.

Zourabichvili, François (2011) La Litteralité et autres essais sur l'art, Paris: Presses universitaires de France.

Zourabichvili, François (2012) Deleuze: A Philosophy of the Event together with The Vocabulary of Deleuze, ed. Gregg Lambert and Daniel W. Smith, trans. Kieran Aarons, Edinburgh: Edinburgh University Press. 